\title{
MICROBIOLOGICAL EVALUATION OF DIFFERENT ANTISEPTIC POVIDONE-IODINE AND CHLORHEXIDINE FORMULATIONS AFTER INTENTIONAL CONTAMINATION OF CONTAINERS
}

\author{
Christiane Moreira Padovani ${ }^{1}$ \\ Kazuko Uchikawa Graziano ${ }^{2}$ \\ Vânia Regina Goveia
}

Padovani CM, Graziano KU, Goveia VR. Microbiological evaluation of different antiseptic povidone-iodine and chlorhexidine formulations after intentional contamination of containers. Rev Latino-am Enfermagem 2008 novembro-dezembro; 16(6):1038-41.

This study aimed to evaluate the survival rate of microorganisms within different antiseptic formulations povidone-iodine (PVP-I) and chlorhexidine ( $\mathrm{CHX}$ ) - after intentional contamination, and to establish the minimum care necessary to ensure sterilization of non-disposable antiseptic solution containers. A laboratory study was performed with 180 antiseptic containers, which were contaminated with Serratia marcescens [1 x 105 UFC/ $m L]$. The containers were closed and stored, at room temperature, during seven days and shaken daily. The antiseptic cultures were evaluated to be $100 \%$ negative to Serratia marcescens in all of the non-disposable containers. These results suggested that antiseptic solutions inactivate microorganisms [ $1 \times 105 \mathrm{UFC} / \mathrm{mL}$ ]. Since cleaned antiseptic containers have around 102 UFC coming from tap water, it can be inferred that cleansing is a safe minimum procedure to ensure reuse of containers for distribution of CHX and PVP-I solutions in aqueous, detergent and alcoholic formulations.

DESCRIPTORS: anti-infective agents, local; contamination; cross infection

\section{EVALUACIÓN MICROBIOLÓGICA DE LAS DIFERENTES FORMULACIONES ANTISÉPTIÇAS, POLIVINIL-PIRROLIDONA-YODO Y CLOREXIDINA, DESPUÉS DE LA CONTAMINACIÓN INTENCIONAL DE LOS RECIPIENTES}

Los objetivos de este estudio fueron evaluar la sobre vivencia de los micro organismos en las diferentes formulaciones de los antisépticos clorexidina ( $\mathrm{CHX}$ ) y polivinil-pirrolidona-yodo (PVP-Y), después de una contaminación intencional de los recipientes y extrapolar los resultados de los laboratorios para el cuidado mínimo a ser dispensado a los recipientes de múltiple uso para el envase de los antisépticos probados. Para esto, fue desarrollado un estudio de laboratorio, en que 180 recipientes fueron contaminados con $1 \times 105$ UFC/ $m L$ de suspensión conteniendo S.marcescens. Después de la contaminación, seis diferentes formulaciones de antisépticos (clorexidina y PVP-Y en los vehículos alcohólico, detergente y acuoso) fueron distribuidos y sometidos a la cultura diaria durante siete días, a fin de verificar se hubo crecimiento del microorganismo. Los resultados de esta investigación permiten recomendar la limpieza como el procedimiento mínimo en el procesamiento de esos recipientes que garantiza la seguridad de su utilización repetida para distribución de los antisépticos que fueron sometidos a prueba - CHX y PVP-Y.

DESCRIPTORES: agentes antiinfecciosos locales; contaminación; infección hospitalar

\section{AVALIAÇ̃̃O MICROBIOLÓGICA DAS DIFERENTES FORMULAÇõES ANTI-SÉPTICAS, POLIVINILPIRROLIDONA-IODO E CLOREXIDINA, APÓS CONTAMINAÇÃO INTENCIONAL DAS ALMOTOLIAS}

Os objetivos deste estudo foram: avaliação da sobrevivência dos microrganismos nas diferentes formulações dos anti-sépticos clorexidina $(\mathrm{CHX})$ e polivinilpirrolidona-iodo (PVP-I), após contaminação intencional das almotolias, e extrapolar os resultados laboratoriais para o cuidado mínimo a ser dispensado às almotolias de múltiplo uso para o envase dos anti-sépticos testados. Para tanto, foi desenvolvido estudo laboratorial, em que 180 almotolias foram contaminadas com 1 × $105 \mathrm{UFC} / \mathrm{mL}$ de suspensão, contendo S.marcescens. Após a contaminação, seis diferentes formulações de anti-sépticos (clorexidina e PVP-I nos veículos alcoólico, degermante e aquoso) foram distribuídas e submetidas à cultura diária durante sete dias, a fim de verificar se houve crescimento do microrganismo. Os resultados desta investigação permitem a recomendação de que a limpeza como procedimento mínimo no processamento desses recipientes garante a segurança de sua utilização repetida para distribuição dos anti-sépticos testados - CHX e PVP-I.

DESCRITORES: antiinfecciosos locais; contaminação; infecção hospitalar

${ }^{1}$ RN, M.Sc. in Nursing, e-mail: chrispadovani@hotmail.com; ${ }^{2}$ Full Professor, University of São Paulo School of Nursing, Brazil, e-mail: kugrazia@usp.br; ${ }^{3}$ RN, Ph.D in Nursing, e-mail: vaniagoveia@uol.com.br. 


\section{INTRODUCTION}

Antiseptics are anti-microbial substances used on skin and mucosa to reduce bacterial counts ${ }^{(1)}$. Attempts to use these agents to prevent infections and reduce their complications originated in Hippocrates' time. Currently, the main use of antiseptics in health institutions is: to cleanse hands, to prepare patients' skin before surgery, to degerm hands and forearms of the surgical team, and in some invasive procedures like central and arterial venous puncture, vascular and vesical catheterism, among others, where the individual's normal barriers of defense are broken ${ }^{(1-2)}$.

Reports found in the literature regarding antiseptic products infected by microbiological contamination are a cause of concern for professionals in the area of infection control related to health care, because these contaminations have been the cause of outbreaks in hospitals ${ }^{(1-2)}$.

Despite uncertainties regarding microbiological resistance to biocides, concentrations currently used in health services are considerably higher that the Minimum Inhibitory Concentration (MIC) of bacteria able to grow in antiseptic solutions ${ }^{(10)}$. The contamination of these solutions is mainly associated to exogenous causes. Inadequate storage and failure in keeping the stability of the product formulation can partially contribute to the apparent contamination found in practice ${ }^{(11)}$.

Contamination related to the processing of containers, whose practice is largely discussed in health services with no scientific basis, was not found among publications on antiseptic contamination. Therefore, this study aimed to evaluate the survival rate of microorganisms within different formulations of antiseptics - CHX and PVPI-I - after intentional contamination of containers with Serratia marcescens and, based on laboratory results, to establish minimum care to be delivered to non-disposable containers used to store antiseptics.

\section{MATERIAL AND METHOD}

Experimental, laboratory study, developed in the Laboratory of Microbiology at the Department of medical-surgery nursing at the University of Sao Paulo, School of Nursing.
Inoculum A sample of the culture Serratia marcescens ATCC 14756 was kept in BHI (Brain Heart Infusion) culture and undercultivated in Tryptone Soy Broth (TSB). After $10^{5} \mathrm{UFC} / \mathrm{ml}$ of inoculum size was confirmed (turbidity equivalent in the McFarland scale), the material was used to contaminate the containers. The inoculation of containers was done in $1 \mathrm{~mL}$ collected through automated mini-pipette and distributed on the entire internal container wall with rotating movements.

Sample size: after the pretest, the experiment sample size was established at 30 samples for each formulation ( $\mathrm{CHX}$ and PVP-I in aqueous, detergent and alcoholic formulations), totaling 180 containers, with $95 \%$ confidence interval $(p<0.05)$.

Experimental planning: The investigated antiseptic solutions - CHX and PVP-I - in the aqueous, detergent and alcoholic formulations were divided in two groups and tested at different moments: Group I - chlorhexidine and Group II - PVP-I. First, 90 containers were intentionally contaminated with $1 \mathrm{~mL}$ of $10^{5} \mathrm{UFC} / \mathrm{mL}$ of $S$. marcescens suspension. The three different formulations of chlorhexidine antiseptic (alcoholic, detergent and aqueous) were distributed in $150 \mathrm{ml}$ volumes. To make sure the experiments were initiated with no microorganisms, all containers were previously cleaned and sterilized with ethylene oxide (ETO).

The containers were lidded and stored at room temperature for seven days and shaken daily, three times a day, at 8AM, 2PM and 8PM, so that the antiseptic solutions would enter in contact with surfaces above the $150 \mathrm{~mL}$ level.

Aliquot parts of $1 \mathrm{~mL}$ of each of the 90 solutions of $\mathrm{CHX}$ in test were pipetted daily and transferred to tubes containing the culture, in order to verify the growth of S. marcescens. Therefore, at the end of seven days, 630 TSB solutions were cultivated (90 per day during seven days) and inoculated with the antiseptic sample contaminated with the test microorganism. The inoculated tubes were incubated at room temperature during 21 days, with daily reading in the first week, and on the $7^{\text {th }}, 14^{\text {th }}$ and $21^{\text {st }}$ days.

After one month, the study continued with group II, using the same work method, in which the PVP-I solutions were tested in the three different formulations (alcoholic, detergent and aqueous).

The media were prepared by adding a specific neutralizer for chlorhexidine (tween $800.5 \%$ ) and for the PVP-I (sodium sulphite $0.1 \%$ ). 
Positive control: growth of test microorganism in $10 \mathrm{~mL}$ of TSB to control the strain viability and equivalence to the prepared media (two tubes).

Negative control: two limpid TSB (two tubes) incubated at $22^{\circ} \mathrm{C}$ for 72 hours indicated absence of microorganisms.

\section{RESULTS}

In the experiments of groups I and II, $100 \%$ of the culture media were kept limpid, evidencing absence of test microorganisms. The negative controls were kept limpid after 21 days of reading. The positive controls became turbid in 24 hours, while a red coloration, characteristic of $S$. Marcescens, was observed in 48 hours. Data on microorganism growth in groups I and II are summarized in table 1.

Table 1 - Distribution of results of microbiological cultures of antiseptic tested in Groups I and II after 21 days of incubation. São Paulo, 2007

\begin{tabular}{ccccc}
\hline Results & $\begin{array}{c}\text { Group I - } \\
\text { CHX }\end{array}$ & $\begin{array}{c}\text { Group II - } \\
\text { PVP-I }\end{array}$ & $\begin{array}{c}\text { Positive } \\
\text { Control }\end{array}$ & $\begin{array}{c}\text { Negative } \\
\text { Control }\end{array}$ \\
\hline Positive Growth & $0 / 630$ & $0 / 630$ & $2 / 2$ & $0 / 2$ \\
Negative Growth & $630 / 630$ & $630 / 630$ & $0 / 2$ & $2 / 2$ \\
\hline
\end{tabular}

\section{DISCUSSION}

The processing of non-disposable containers is a practice not explained in the literature and largely discussed in health services with no scientific basis. The method used to search for the minimum procedure indicated for the processing of these containers was to verify the antiseptics' capacity to inactivate microorganisms intentionally inoculated in the containers through contamination in the order of $1 \mathrm{x}$ $105 \mathrm{UFC} / \mathrm{mL}$. This inoculum was considered strong due to the potential contamination antiseptics would be exposed to when bottled in containers cleaned only with tap water and detergent.

When the results of this study are extrapolated, cleansing is verified to be the minimum procedure required before safe reuse of containers, because the load of microorganisms present in the cleaned container would certainly be smaller that the inoculum challenge of $1 \times 10^{5} \mathrm{UFC} / \mathrm{mL}$. Therefore, a new challenge emerges in the processing of these containers: the heterogeneous contamination of the rinse water. Researchers have showed there is low microbiological load in surgical material after cleaning, on the average $10^{2}$ UFC/ material ${ }^{(12-14)}$.

The legal parameters for water potability, Rule no 518 of March $25^{\text {th }}, 2004$, issued by the Brazilian Ministry of Health, "establishes the procedures and responsibilities related to the control and surveillance of water quality for human consumption and its potability standards, in addition to other necessary

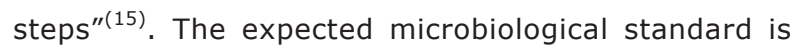
found with a tolerance of contamination much lower than the tested inoculum in this study: absence of $E$. coli or thermotolerant coliforms in $100 \mathrm{~mL}$ of water.

This is an original in vitro study, since publications that presented contamination of antiseptics result from outbreaks in care practice. In Brazil, laboratory studies on microbiological action of biocides gained expression as from the $1980 \mathrm{~s}^{(16)}$.

The main references consulted on antiseptic contamination appoint issues of handling and inadequate care that lead to product instability and allow microorganisms to grow $^{(3-6)}$.

Cases of antiseptic contamination were also reported with findings of organic debris in the solution and biofilm on internal container walls, evidenced by electronic microscopy ${ }^{(7-9)}$. Their presence might have provided protection to the contaminant. The formation of biofilm is a process in which microorganisms irreversibly adhere and grow on the surface, producing extracellular polymer that ease adherence and matrix formation. However, physical methods, such as mechanical cleansing or friction, or even ultrasound, are effective in assuring its removal, provided that it is adequately performed ${ }^{(17)}$.

As previously mentioned, concentrations currently used in health services are substantially higher than the Minimum Inhibitor Concentration of these bacteria(10). Thus, the contamination of antiseptic solutions is not currently associated to reduced susceptibility of microorganisms.

Deductive reasoning was used in this study to conclude that cleaning is the minimum procedure for processing containers in which antiseptics are bottled. This consideration is strongly based on studies that confirm that the number of microorganisms recovered from only cleaned material is around $10^{2}$ UFC ${ }^{(12-14)}$. Considering this deductive reasoning, adequate care with cleaning, rinsing, and drying containers is important for safety control. Residues of detergent can occasionally destabilize chemical formulations, and residues from rinse water can dilute antiseptic concentration. 
Further studies can confirm this deductive reasoning, analyzing residual microorganisms (quantitatively and qualitatively) in containers cleaned only with tap water and detergent in different hospital institutions.

Finally, results of this study provide answers for container processing practice, which was not scientifically based yet. It can be affirmed that the repetitive use of these containers after the cleaning process is a safe practice, making the process easy and economical for the centers of material sterilization in health institutions. Another aspect worth mentioning is the ecological issue involved, with reduced generation of residues from disposable products in the health services.

\section{REFERENCES}

1. Center for Disease Control and Prevention (CDC). Guideline for Hand Hygiene in Health-Care Settings. MMWR 2002; 51 $(\mathrm{RR}-16): 1-45$.

2. USA Food and Drug Administration. Department of Health and Human Services. Monograph for Health-Care Antiseptic Drug Products; Part III. Proposed Rule, 59 Federal Register; 1994.

3. Gómez R, Melero MI, García PP, Altes AG, García MA, Jiménez $C$, et al. Outbreak of Burkhloderia cepacia caused by contaminated chlorhexidine in a hemodialysis unit. Infect Control Hosp Epidemiol 2008; 29(4):377-8.

4. Goetz A, Muder RR. Pseudomonas aeruginosa infections associated with use of povidone - iodine in patients receiving continuous ambulatory peritoneal dialysis. Infec Control Hosp Epidemiol 1989; 10(10):447-9.

5. Archibald LK, Corl A, Shah B, Schlte M, Arduino MJ, Aguero $S$, et al. Serratia marcescens outbreak associated with extrinsic contamination of $1 \%$ chloroxylenol soap. Infect Control Hosp Epidemiol 1997; 18(10):704-9.

6. Vigeant $P$, Loo VG, Bertrand C. An outbraeak of Serratia Marcescens infections related to contaminated chlorhexidine. Infect Control Hosp Epidemiol 1998; 19:791-4.

7. Marrie TJ, Costerton W. Prolonged survival of Serratia marcescens in chlorhexidine. Appl Environ Microbiol 1981; 42(6): 1093-102.

8. Berkelman RL, Lewin $S$, Allen JR, Anderson RL, Budnick LD, Shapiro $S$, et al. Pseudobacteremia attibuted to contamination of povidone-iodine with Pseudomonas cepacia. An Inter Med 1981; 95: 32-6.

9. Anderson RL, Vess RW, Panlilio AL, Faver MS. Prolongaded

\section{CONCLUSION}

This study allowed for the following conclusions:

Tested antiseptic (chlorhexidine and PVP-I in aqueous, detergent and alcoholic solutions) inactivated microorganisms intentionally inoculated in containers in a concentration of $1 \times 10^{5} \mathrm{UFC} / \mathrm{mL}$.

Considering that cleaned containers carry vegetative microorganisms from the rinse water in the order of $10^{2}$ UFC, it can be inferred that cleaning is considered safe as a minimum procedure for repetitive use of these containers in the distribution of the tested antiseptics - chlorhexidine and PVP-I, in detergent, aqueous and alcoholic formulations.

survival of Pseudomonas cepacia in commercially manufactured povidone-iodine. Appl Environ Microbiol 1990; $56: 3598-600$.

10. Russel AD. Bacterial adaptation and resistance to antiseptics, disinfectants and preservatives is a not a new phenomenon. J Hosp Infect 2004; 57:97-104.

11. Spainhour S. Letters to the Editor. Serratia marcencens outbreak assiciated with extrinsic contamination of $1 \%$ chloroxylenol soap. Infect Control Hosp Epidemiol 1998; (18):476.

12. Chan-myers H, Mcalister D, Antonoplos P. Natural bioburden levels detected on rigid lumened medical devices before and after cleaning. Am J Infect Control 1997; 25(6): 471-6.

13. Chu NS, Chan-Myers H, Ghazanfari N, Antonoplos P. Levels of naturally occurring microorganisms on surgical instruments after clinical use and after washing. Am J Infect Control 1999; 27:315-9.

14. Rutala WA, Gergen MF, Jones JF, Weber DJ. Levels of microbial contamination on surgical instruments. Am J Infect Control 1998; 26:143-5.

15. Ministério da Saúde [homepage na Internet] Brasília: Ministério da Saúde; [Acessado em 2007 janeiro 14]. Portaria no 518, de 25 de março de 2004. Estabelece os procedimentos e responsabilidades relativos ao controle e vigilância da qualidade da água para consumo humano e seu padrão de potabilidade, e dá outras providências. Disponível em: http://www.anvisa.gov.br/e-legis.

16. Lacerda RA. Produção científica sobre infecção hospitalar e a contribuição da enfermagem: ontem, hoje e perspectivas. Rev Latino-am Enfermagem 2002; 10(1):55-63.

17. Donlan RM. Biofilm and device-associated infection. Emerging Infect Dis 2001; 7(2): 277-81. 